\title{
GAMBARAN TINGKAT SELF-EFFICACY IBU POST SEKSIO SESAREA SAAT MENYUSUI DI RSKIA KOTA BANDUNG
}

\author{
${ }^{1}$ Masriyah Komalasari, ${ }^{2}$ Tetti Solehati, ${ }^{3}$ Efri Widianti \\ ${ }^{1,2,3}$ Fakultas Keperawatan Universitas Padjadjaran \\ Email: ${ }^{1}$ masriyahksari@gmail.com
}

\begin{abstract}
ABSTRAK
Rendahnya cakupan pemberian ASI ekslusif di Indonesia disebabkan oleh faktor fisik dan psikologis ibu. Faktor fisik yang dapat menghambat ibu untuk menyusui dapat disebabkan oleh metode persalinan salah satunya seksio sesarea. Sedangkan faktor psikologis yang berpengaruh terhadap menyusui adalah selfefficacy ibu. Self-efficacy dalam menyusui dapat berpengaruh pada komitmen dalam menyusui, daya tahan ibu dalam mengatasi hambatan yang muncul saat menyusu dan fokus ibu pada aspek positif atau negatif dalam menyusui. Dengan diketahuinya self-effiacy ibu, petugas kesehatan dapat memberikan intervensi berupa motivasi dan pendidikan kesehatan dengan segera agar ibu tetap berkomitmen untuk menyusui. Penelitian ini bertujuan untuk mengetahui tingkat self efficacy ibu dalam menyusui pada ibu post seksio sesarea di ruang nifas RSKIA Kota Bandung. Rancangan penelitian ini menggunakan deskriptif kuantitatif. Teknik sampling yang digunakan adalah purposive sampling. Penelitian melibatkan 77 responden. Instrumen yang digunakan berupa kuesioner yang dibuat oleh peneliti dengan mengacu pada teori selfefficacy dalam menyusui Bandura (1997) dan Dennis (2003) serta teori menyusui Murray \& McKinney (2014). Analisa data menggunakan mean.. Berdasarkan dimensi teknik lebih dari setengah responden memiliki tingkat self-efficacy rendah (54.5\%) dan pada dimensi kepercayaan intrapersonal juga didapatkan lebih dari setengah responden memiliki tingkat self-efficacy rendah (53.2\%). Kondisi tersebut menggambarkan bahwa masih rendahnya keyakinan ibu akan pemahamannya dalam menyusui dan rendahnya keyakinan ibu untuk melaksanakan tugas menyusui sebagaimana melaksanakan tugas lainnya. Sedangkan berdasarkan dimensi dukungan, lebih dari setengah responden memiliki tingkat self efficacy tinggi (50.6\%). Kondisi tersebut menggambarkan bahwa dukungan untuk menyusui yang ibu dapatkan dirasa telah optimal. Simpulan dari penelitian ini menunjukkan rendahnya tingkat self-efficacy ibu dalam menyusui. Kondisi tersebut menggambarkan bahwa masih rendahnya komitmen dalam menyusui, rendahnya daya tahan ibu dalam mengatasi hambatan yang muncul saat menyusu dan fokus ibu pada aspek negatif dalam menyusui. Oleh karena itu, petugas kesehatan sebaiknya memberikan psikoedukasi mengenai menyusui pada satu persatu ibu secara lebih optimal.
\end{abstract}

Kata kunci: Menyusui, Seksio sesarea, \& Self-efficacy.

\section{ABSTRACT}

The low rate of exclusive breastfeeding in Indonesia are caused by mother's physical and psychological factors. Physical factors that may inhibit mothers to breastfeed can be caused by the delivery methods. One of them was cesarean section method. Psychological factors that influenced breastfeeding mother was self-efficacy. Breastfeeding self-efficacy would determine the success of breastfeeding. This studied aims to described the level of breastfeeding self-efficacy on post caesarean section mothers in RSKIA Bandung. The design of this studied used descriptive quantitative. Sampling technique of this studied used purposive sampling. The studied involved 77 respondents. The instrument used was an instrument made by researchers with Cronbach alpha value is 0.97 and a validity value in the range of 0.516-0.911. Data was analyzed used mean. The results showed that more than half of respondents (51.9\%) had a low level of selfefficacy, while less than half of respondents (48.1\%) had higher levels of self-efficacy. Based on techniques dimensions, more than half of respondents had a low level of self-efficacy (54.5\%). Based on intrapersonal trust dimensions, more than half of respondents had a low level of self-efficacy (53.2\%). While based on the support dimensions, more than half of respondents had a high level of self-efficacy (50.6\%). The conclusions of this studied showed that low breastfeeding self-efficacy level can lead to breastfeed failure. Therefore, health professionals should provide psycho-education about breastfeeding at one by one mother optimally.

Keywords: breastfeeding, caesarean section, self-efficacy 


\section{PENDAHULUAN}

Pemberian Air Susu Ibu (ASI) merupakan cara yang alami untuk memberikan nutrisi pada bayi, terutama bayi baru lahir. WHO dan Unicef merekomendasikan sebaiknya bayi hanya disusui ASI saja selama enam bulan (WHO, 2014).

Di Indonesia, angka pemberian ASI esklusif baru mencapai $52,3 \%$ dengan estimasi absolut bayi tidak ASI ekslusif terbanyak di Provinsi Jawa Barat yaitu sebanyak 21,3\%. Menurut Data Profil Kesehatan Provinsi Jawa Barat tahun 2012, di Kota Bandung presentase pemberian ASI esklusif hanya sebanyak $12,5 \%$. Dari angka diatas, cakupan pemberian ASI esklusif masih tergolong jauh dari angka yang ditargetkan nasional yaitu $80 \%$ (Kemenkes RI, 2015).

Berdasarkan hasil penelitian Sullivan (2014) diketahui bahwa terdapat hubungan antara metode persalinan dengan angka pemberian ASI. Pada persalinan dengan tindakan seksio sesarea,selain mengalami perubahan fisiologis pada masa nifas terutama involusi dan laktasi, akan timbul pula rasa nyeri di sekitar luka sayatan operasi (Wiklund, et al., 2008).

Selain itu juga, ibu yang mengalami operasi seksio sesarea tidak mungkin dapat menyusui bayinya segera karena ibu belum sadar akibat efek anestesi. Efek anestesi yang mempengaruhi bayi juga dapat mengakibatkan bayi lemah dan malas menyusu sehingga tidak ada rangsangan hisap pada payudara ibu dan akibatnya proses laktasi akan terhambat (Lin,et al., 2011).

Selain berasal dari faktor fisik, terhambatnya produksi ASI juga dapat dipengaruhi oleh faktor psikologis ibu. Ibu yang merasa produksi ASI nya kurang, cenderung memiliki keyakinan diri yang rendah dalam menyusui (Blyth,et al., 2002). Keyakinan diri atau yang kita ketahui sebagai self-efficacy adalah keyakinan seseorang bahwa dirinya mampu melaksanankan suatu tindakan tertentu. (Bandura, 1997).

Dennis (1999) kemudian menelaah lebih jauh tentang hubungan antara selfefficacy dan menyusui, sehingga muncul istilah self-efficacy dalam menyusui. Selfefficacy dalam menyusui merupakan keyakinan diri seorang ibu terhadap kemampuan diri untuk menyusui bayinya. Self-efficacy dalam menyusui akan menentukan apakah ibu akan menyusui bayinya atau tidak dan bagaimana ibu bereaksi terhadap semua kesulitan yang dihadapi saat menyusui (Dennis, 1999). Rendahnya self-efficacy dapat mengakibatkan rendahnya komitmen dalam menyusui, rendahnya daya tahan ibu dalam mengatasi hambatan yang muncul saat menyusu dan berfokus pada aspek negatif dalam menyusui (Bandura, 1997 dalam Spaulding \& Gore, 2009).

Pentingnya self-efficacy dalam menyusui telah dibuktikan oleh beberapa penelitian. Berdasarkan penelitian yang dilakukan oleh Pollard dan Guill (2010) menemukan bahwa terdapat hubungan antara tingkat self-efficacy dalam menyusui dengan durasi menyusui. Ibu yang mempunyai tingkat self-efficacy dalam menyusui yang tinggi akan menyusui lebih lama dibandingkan dengan ibu dengan tingkat selfefficacy dalam menyusui yang rendah. Selain itu juga, ibu yang memiliki self-efficacy yang tinggi akan menginterpretasikan kesulitan dalam menyusui sebagai tantangan yang positif dan mempersepsikan kesulitan sebagai hal yang normal. Berdasarkan hasil penelitian yang dilakukan oleh Kurniawan (2013) menunjukkan bahwa self-efficacy ibu yang tinggi untuk memberikan ASI ekslusif didapatkan pada sebagian besar ibu yang berhasil memberikan ASI ekslusif. Penelitian tersebut didukung oleh penelitian yang dilakukan oleh Fahriani (2014) yang mengatakan bahwa faktor yang terbukti memengaruhi pemberian ASI eksklusif adalah faktor psikologis ibu yaitu self-efficacy. 
Menurut Dennis (1999) self-efficacy terdiri dari tiga dimensi yaitu dimensi teknik, dimensi kepercayaan intrapersonal dan dimensi dukungan. Dimensi teknik merupakan segala hal yang berhubungan dengan aktivitas fisik seseorang dan tindakan untuk mencapai keberhasilan dalam proses menyusui. Dimensi kepercayaan intrapersonal meliputi keyakinan, persepsi dan sikap ibu terhadap perilaku menyusui. Sedangkan dimensi dukungan meliputi semua hal yang mendukung ibu untuk menyusui dengan baik yang melibatkan emosional maupun fisik.

Berdasarkan studi pendahuluan kepada 12 orang ibu post seksio sesarea di RSKIA Kota Bandung, diketahui bahwa delapan orang ibu tidak yakin dapat mencukupi kebutuhan ASI bagi bayinya. Hal ini dikarenakan adanya nyeri akibat pembedahan sehingga membuat ibu merasa terganggu dalam menyusui dan membuat ibu tidak yakin dapat menyusui bayinya setiap kali ingin menyusu. Selain luka operasi, adanya dampak anestesi mempengaruhi bayi sehingga bayi terus menerus tidur dan malas untuk menyusu.

Sesuai dengan masalah yang telah dipaparkan, maka penulis akan melakukan penelitian mengenai gambaran tingkat selfefficacy dalam menyusui pada ibu post seksio sesarea di RSKIA Kota Bandung.

\section{METODE}

Self-efficacy dalam menyusui merupakan variabel yang sangat penting dalam menentukan keputusan ibu dalam menyusui. Menurut Dennis (2003, dalam Sullivan, 2014) self-efficacy dalam menyusui dapat memprediksi apakah ibu memilih menyusui atau tidak, berapa banyak usaha yang dilakukan ibu untuk menyusui bayinya, bagaimana pola pikir ibu untuk menyusui bayinya, meningkat atau menyerah, dan bagaimana ibu menanggapi secara emosional untuk menyusui bayinya.

\begin{tabular}{llr}
\multicolumn{2}{c}{ Desain penelitian yang dilakukan } \\
adalah deskriptif-kuantitatif
\end{tabular}

pendekatan cross sectional. Populasi dalam penelitian ini adalah ibu post seksio sesarea di RSKIA Kota Bandung dengan teknik pengambilan sampel yang digunakan adalah purposive sampling dengan jumlah 77 responden.

Instrumen yang digunakan berupa kuesioner untuk mengukur self-efficacy ibu dalam menyusui sebanyak 46 pertanyaan berupa skala likert. Instrumen mengacu pada teori self-efficacy dalam menyusui Bandura (1997) dan Dennis (2003) yang membagi selfefficacy kedalam tiga dimensi dan pertanyaan masing-masing dimensi didukung oleh teori menyusui Murray \& McKinney (2014). Instrumen telah diuji validitas reliabilitasnya dengan nilai validitas berada dalam rentang 0.516-0.911 dan nilai cronbach's alpha coefficient yang didapatkan adalah 0.967.

Analisa data yang digunakan pada penelitian ini menggunakan mean karena data berdistribusi normal. Mean skor self-efficacy yang didapatkan digunakan untuk menentukkan rendah tingginya self-efficacy. Jika skor kurang dari mean, maka dapat disimpulkan self-efficacy rendah dan sebaliknya, jika skor lebih dari mean maka dapat disimpulkan self-efficacy tinggi.

Penelitian ini dilakukaan di Ruang Nifas RSKIA Kota Bandung pada Bulan MeiJuni 2016.

\section{HASIL}

Berdasarkan penelitian didapatkan hasil sebagai berikut:

Tabel 1. Distribusi Frekuensi Self-efficacy Ibu Post Seksio Sesarea saat Menyusui di RSKIA Kota Bandung Bulan Mei-Juni Tahun 2016 $(\mathrm{N}=77)$

\begin{tabular}{lcc}
\hline Self-efficacy & F & \% \\
\hline Rendah & 42 & 54,5 \\
Tinggi & 35 & 45,5 \\
\hline
\end{tabular}

Berdasarkan tabel 1 dapat diketahui bahwa dari keseluruhan responden, lebih dari setengah responden $(51,9 \%)$ termasuk dalam kategori self-efficacy rendah dan kurang dari 
setengah responden $(48,1 \%)$ termasuk dalam kategori self-efficacy tinggi.

Tabel 2. Distribusi Frekuensi Self-efficacy Ibu Post Seksio Sesarea saat Menyusui Berdasarkan Dimensi di RSKIA Kota Bandung Bulan Mei-Juni Tahun $2016(\mathrm{~N}=77)$

\begin{tabular}{lcccc}
\hline \multirow{2}{*}{ Dimensi } & \multicolumn{4}{c}{ Self-efficacy } \\
\cline { 2 - 5 } Self Efficacy & \multicolumn{2}{c}{ Rendah } & \multicolumn{2}{c}{ Tinggi } \\
\cline { 2 - 5 } & F & \% & F & \% \\
\hline Teknik & 42 & 54,5 & 35 & 45,5 \\
Kepercayaan & 41 & 53,2 & 36 & 46,8 \\
Intrapersonal & & & & \\
Dukungan & 38 & 49,4 & 39 & 50,6 \\
\hline
\end{tabular}

Berdasarkan tabel 2 dapat diketahui bahwa pada dimensi teknik, lebih dari setengah responden mempunyai tingkat selfefficacy rendah $(54,5 \%)$ dan kurang dari setengah responden memiliki tingkat selfefficacy tinggi (45,5\%). Pada dimensi kepercayaan intarpersonal, lebih dari setengah responden mempunyai tingkat self-efficacy rendah $(53,2 \%)$ dan kurang dari setengah responden memiliki tingkat self-efficacy tinggi (46,8\%). Sedangkan pada dimensi dukungan, kurang dari setengah responden mempunyai tingkat self-efficacy rendah $(49,4 \%)$ dan lebih dari setengah responden memiliki tingkat self-efficacy tinggi (50,6\%).

Untuk melihat item pertanyaan mana saja yang rata-ratanya paling rendah dan memudahkan untuk megevaluasi self-efficacy ibu secara tepat sasaran maka disajikan tabel berikut.

Tabel 3. Rerata Skor Item Pertanyaan Self-efficacy Ibu Post Seksio Sesarea saat Menyusui Berdasarkan Dimensi Teknik di RSKIA Kota Bandung Bulan Mei-Juni Tahun 2016 (N=77)

\begin{tabular}{lc}
\hline Item Pertanyaan & Mean \\
\hline Ketepatan waktu menyusui. & 2,32 \\
Tahu tanda bayi ingin menyusu. & 2,58 \\
Posisi tubuh bayi saat menyusu. & 2,62 \\
Posisi mulut bayi saat menyusu. & 2,71 \\
Menyusui 8-12 x/hari. & 2,80 \\
Melihat ASI di mulut bayi setiap & 2,88 \\
menghisap. & \\
Memposisikan bayi dengan nyaman. & 2,90 \\
Memposisikan bayi untuk bersendawa. & 2,99 \\
Nyaman sebelum menyusui. & 3,01 \\
Memonitor kenaikan berat badan bayi. & 3,04
\end{tabular}

Mendengar bayi menelan saat 3,10 menyusui.

Membersihkan payudara sebelum 3,15 menyusui.

Melepaskan mulut bayi dari puting $\quad 3,18$

saat berhenti menghisap.

ASI dalam payudara berkurang/habis $\quad 3,18$

setelah menyusui.

Bayi menghisap kuat. $\quad 3,21$

Menyusui pada payudara secara $\quad 3,21$

bergantian.

Menyusui 10-15 menit atau lebih.

3,25

Berdasarkan tabel 3 dapat diketahui bahwa rata-rata keyakinan terendah ibu berada pada aspek ketepatan waktu dalam menyusui $($ mean $=2,32)$, pengetahuan mengenai tanda bayi ingin menyusu (mean= 2,58 ), posisi tubuh bayi saat menyusu (mean= 2,62 ) dan posisi mulut bayi saat menyusu $($ mean $=2,72)$.

Tabel 4. Rerata Skor Item Pertanyaan Self-efficacy Ibu Post Seksio Sesarea saat Menyusui Berdasarkan Dimensi Kepercayaan Intrapersonal di RSKIA Kota Bandung Bulan Mei-Juni Tahun $2016(n=77)$

\begin{tabular}{lc}
\hline Item Pertanyaan & Mean \\
\hline $\begin{array}{l}\text { Puting tidak akan lecet setelah } \\
\text { menyusui. }\end{array}$ & 2,88 \\
$\begin{array}{l}\text { Payudara tidak akan bengkak setelah } \\
\text { menyusui. }\end{array}$ & 3,06 \\
$\begin{array}{l}\text { Memberikan ASI tanpa menggunakan } \\
\text { dot. }\end{array}$ & 3,08 \\
$\begin{array}{l}\text { Menyusui walaupun mengalami rasa } \\
\text { nyeri. }\end{array}$ & 3,12 \\
$\begin{array}{l}\text { Menyusui sesuai kebutuhan bayi. } \\
\text { Memberikan ASI sampai dengan usia }\end{array}$ & 3,12 \\
$\begin{array}{l}\text { 2 tahun. } \\
\text { Mengatasi hambatan dari luar saat } \\
\text { menyusui. }\end{array}$ & 3,23 \\
$\begin{array}{l}\text { Memfokuskan diri saat menyusui. } \\
\text { Memberikan ASI ekslusif. }\end{array}$ & 3,27 \\
\hline
\end{tabular}

Berdasarkan tabel 4 dapat diketahui bahwa rata-rata keyakinan terendah ibu berada pada aspek keyakinan puting tidak akan lecet $($ mean $=2,88)$, payudara tidak akan bengkak (mean $=3,06)$, memberikan ASI tanpa dot (mean $=3,08)$, menyusui walaupun mengalami rasa nyeri (mean $=3,12)$ dan menyusui sesuai kebutuhan bayi (mean 3,12). 
Tabel 5. Rerata Skor Item Pertanyaan Self-efficacy Ibu Post Seksio Sesarea saat Menyusui Berdasarkan Dimensi Dukungan di RSKIA Kota Bandung Bulan Mei-Juni Tahun 2016 (n=77)

\begin{tabular}{|c|c|c|}
\hline \multicolumn{2}{|c|}{ Item Pertanyaan } & \multirow{2}{*}{$\frac{\text { Mean }}{3,05}$} \\
\hline Suami & Informasi & \\
\hline$($ mean $=$ & Motivasi & 3,26 \\
\hline \multirow[t]{2}{*}{$3,13)$} & Posisi & 3,10 \\
\hline & Pujian & 3,10 \\
\hline \multirow{4}{*}{$\begin{array}{l}\text { Keluarga } \\
(\text { mean }= \\
3,20)\end{array}$} & Tips & 3,14 \\
\hline & Motivasi & 3,34 \\
\hline & Posisi & 3,15 \\
\hline & Pujian & 3,18 \\
\hline \multirow{8}{*}{$\begin{array}{l}\text { Petugas } \\
\text { Kesehatan } \\
(\text { mean }= \\
2,98)\end{array}$} & Informasi pencegahan & 3,00 \\
\hline & $\begin{array}{l}\text { lecet pada puting. } \\
\text { Informasi pencegahan } \\
\text { bengkak pada } \\
\text { payudara. }\end{array}$ & 2,92 \\
\hline & $\begin{array}{l}\text { Informasi perawatan } \\
\text { payudara. }\end{array}$ & 2,86 \\
\hline & $\begin{array}{l}\text { Informasi nutrisi saat } \\
\text { menyusui. }\end{array}$ & 2,99 \\
\hline & $\begin{array}{l}\text { Informasi tanda } \\
\text { kecukupan ASI bagi } \\
\text { ibu dan bayi. }\end{array}$ & 2,99 \\
\hline & Motivasi & 3,17 \\
\hline & $\begin{array}{l}\text { Mengatasi keluhan saat } \\
\text { menyusui. }\end{array}$ & 2,95 \\
\hline & Pujian & 2,96 \\
\hline \multirow{4}{*}{$\begin{array}{l}\text { Teman } \\
(\text { mean }= \\
2,75)\end{array}$} & Tips & 2,84 \\
\hline & Motivasi & 2,86 \\
\hline & Posisi & 2,61 \\
\hline & Pujian & 2,69 \\
\hline
\end{tabular}

Berdasarkan tabel 5 dapat diketahui bahwa rata-rata keyakinan terendah ibu berada pada dukungan yang berasal dari teman (mean $=2,75$ ) baik dukungan dalam membantu posisi ibu saat menyusui (mean= 2,61), pujian yang didapatkan ibu jika berhasil menyusui (mean= 2,69), dukungan dalam memberikan tips dalam menyusui (mean $=2,84)$ dan motivasi yang didapatkan (mean $=2,86$ ). Sedangkan dukungan tertinggi didapatkan berasal dari keluarga (mean $=3,2$ ) dan suami (mean $=3,13$ ) terutama dalam hal motivasi yang diberikan kepada ibu untuk memberikan ASI.

\section{PEMBAHASAN}

\section{Self-Efficacy Dalam Menyusui}

Berdasarkan hasil penelitian, lebih dari setengah responden memiliki self-efficacy dalam menyusui yang rendah. Rendahnya tingkat self-efficacy dalam menyusui menggambarkan bahwa masih kurangnya keyakinan ibu post seksio sesarea mengenai kemampuannya dalam menyusui.

Persalinan dengan tindakan seksio dapat menimbulkan nyeri luka operasi (Karlström, et al., 2007). Hal tersebut membuat ibu kesulitan saat bergerak dan merawat bayinya terutama saat menyusui. Selain itu juga kekhawatiran ibu mengenai akan bengkaknya payudara dan lecetnya puting setelah menyusui juga dapat menyebabkan self-efficacy ibu untuk menyusui menjadi rendah. Kedua interpretasi negatif tersebutlah yang dapat menyebabkan terhambatnya refleks let down sehingga aliran ASI pun akan berkurang sehingga menyusui pun tidak akan berhasil.

Rendahnya skor self-efficacy juga disebabkan oleh karena kurangnya bimbingan petugas kesehatan mengenai pelaksanaan menyusui sehingga pembelajaran yang ibu dapatkan kurang dipahami oleh ibu. Terbukti dengan masih rendahnya self-efficacy ibu dalam menyusui jika dilihat dari dimensi teknik.Oleh karena itu sebaiknya ibu diajarkan selama beberapa kali lalu observasi ibu ketika mulai menyusui sendiri dan evaluasi kesulitan apa saja yang dirasakan.

Rendahnya tingkat self-efficacy ibu dalam menyusui dapat mempengaruhi komitmen ibu terhadap pemberian keberhasilan pemberian ASI ekslusif. Ibu dengan tingkat self-efficacy yang rendah cenderung berfokus pada aspek negatif dalam menyusui seperti berfokus pada nyeri dan cemas yang ibu rasakan saat menyusui. Kurangnya usaha dan daya tahan ibu dalam menghadapi kesulitan saat menyusui inilah yang akan membuat ibu berhenti menyusui lebih awal dan beralih menggunakan susu formula. Hal ini didukung oleh penelitian Kurniawan (2013) yang menyatakan bahwa ibu yang memiliki tingkat self-efficacy yang 
rendah didapatkan sebagian besar pada ibu yang gagal memberikan ASI ekslusif.

\section{Self-Efficacy Dalam Menyusui Berdasarkan Dimensi Teknik}

Jika dilihat dari dimensi teknik, lebih dari setengah responden memiliki tingkat selfefficacy yang rendah. Rendahnya dimensi ini disebabkan oleh kurangnya pengetahuan dan pemahaman ibu mengenai proses menyusui terkait teknik menyusui yang baik dan benar dan respon bayi saat menyusu. Rata-rata teknik terendah yang belum dipahami oleh ibu adalah ketepatan waktu dalam menyusui $($ mean $=2,32)$. Ketidaktepatan ibu dalam menyusui dapat dipengaruhi oleh kurangnya keyakinan ibu mengenai pengetahuannya akan tanda bayi ingin menyusu (mean=2,58). Sebagian besar ibu tidak dapat mendeteksi tanda awal bayi ingin menyusu dan hanya menyusui ketika anaknya telah menangis tanpa memperhatikan tanda awal yang muncul. Padahal sebenarnya menurut Murray dan McKinney (2014), menyusui setelah bayi menangis mengindikasikan bahwa ibu tidak menyusui anaknya dengan tepat waktu.

Rata-rata ibu juga masih kurang yakin dalam memposisikan bayi dengan benar saat menyusu (mean= 2,62). Sebagian besar ibu merasa khawatir bayi sulit bernapas jika hidung bayi menyentuh payudara sehingga hanya pipi dan dagu bayi saja yang menempel pada payudara ibu. Walaupun payudara ibu berat dan hidung bayi tenggelam dalam payudara ibu, pernapasan bayi tidak akan terganggu. Justru posisi hidung, pipi dan dagu bayi yang tidak menyentuh payudara dapat berpengaruh pada aliran ASI (Murray \& McKinney, 2014).

Selain itu juga ibu masih kurang yakin dalam memposisikan mulut bayi pada areola mamae $($ mean $=2,71)$. Sebagian besar ibu hanya memasukkan puting saja ke mulut bayi, padahal seharusnya menurut Murray dan McKinney (2014) mulut bayi harus berada pada areola 2,5 sampai $3,8 \mathrm{~cm}$ dari puting susu untuk mencegah bayi menghisap hanya puting saja. Mulut bayi yang tidak berada pada posisi yang tepat pada areola akan membuat reflek menghisap bayi tidak optimal sehingga ASI yang diproduksi pun sedikit bahkan akan terjadi kelecetan pada puting susu ibu.

Rendahnya tingkat self-efficacy pada dimensi ini disebabkan oleh adanya rasa nyeri pada luka operasi. Dengan adanya nyeri, ibu akan kesulitan dalam bergerak dan memposisikan bayinya dalam menyusui. Ibu juga akan terfokus pada rasa nyerinya sehingga tidak memperhatikan teknik yang benar dalam menyusui. Hal ini didukung oleh hasil penelitian Karlström, et al (2007) yang menyatakan bahwa sebanyak $78 \%$ ibu merasakan bahwa nyeri yang dirasakan berada diatas skala 4. Hal tersebut membuat $70 \%$ ibu mengalami kesulitan dalam memposisikan bayi saat menyusui.

Selain adanya nyeri, kurangnya pengetahuan dan pemahaman ibu mengenai teknik menyusui yang benar dapat berdampak pada rendahnya skor self-efficacy ibu. Rendahnya pengetahuan ibu dapat dikarenakan tidak intensif dan lengkapnya informasi yang ibu terima mengenai ASI ekslusif, kandungan dan manfaat ASI, teknik menyusui dan kerugian jika tidak memberikan ASI ekslusif. Anggapan ibu bahwa menyusui merupakan suatu proses yang alami tanpa harus dipelajari juga dapat berkontribusi dalam rendahnya tingkat selfefficacy pada dimensi teknik (Rinata, 2015).

\section{Self-Efficacy Dalam Menyusui Berdasarkan Dimensi Kepercayaan Intrapersonal}

Pada dimensi kepercayaan intrapersonal, lebih dari setengah responden memiliki tingkat self-efficacy yang rendah. Hal ini disebabkan oleh rendahnya keyakinan yang ibu miliki untuk melaksanakan tugas menyusui sebagaimana melaksanakan tugas lainnya serta belum optimalnya usaha dan daya tahan ibu dalam menghadapi kesulitan saat menyusui. Rendahnya keyakinan ibu pada dimensi ini juga berkaitan dengan 
rendahnya pemahaman ibu mengenai teknik menyusui yang benar. Kurangnya pemahaman dan pengetahuan ibu mengenai teknik menyusui akan berdampak pada menurunnya kepercayaan diri dan keyakinan ibu terhadap pemberian ASI.

Keyakinan yang rendah rata-rata didapatkan pada kurangnya keyakinan ibu bahwa putingnya tidak akan lecet (mean= 2,88 ) dan payudaranya tidak akan bengkak setelah menyusui (mean $=3,06$ ). Hal ini sejalan dengan hasil penelitian yang dilakukan oleh Coca (2008) yaitu masalah yang paling sering dialami oleh ibu menyusui adalah puting susu lecet dan bengkak. Menurut Murray dan McKinney (2014) rendahnya keyakinan ibu bahwa payudaranya tidak akan lecet dapat diakibatkan oleh kurangnya keyakinan ibu mengenai teknik perlekatan dalam menyusui baik perlekatan antara tubuh bayi dan ibu maupun perlekatan mulut bayi pada puting ibu saat menyusui. Sedangkan rendahnya keyakinan ibu bahwa payudaranya tidak akan bengkak setelah menyusui dapat diakibatkan oleh kurangnya keyakinan ibu akan ketepatan waktu dalam menyusui dan ibu tidak menyusui sesering mungkin terutama pada malam hari. Padahal saat malam hari, hormon prolaktin meningkat sehingga pasokan ASI akan tetap terjaga dan payudara ibu dapat terhindar dari bengkak jika ibu memberikan ASI pada malam hari.

Selain itu juga, keyakinan yang rendah rata-rata didapatkan pada kurangnya keyakinan ibu akan kemampuan menyusui saat rasa nyeri muncul (mean $=3,12)$. Adanya rasa nyeri yang dalam hal ini diakibatkan oleh luka operasi dapat membuat ibu mengalami kesulitan dalam bergerak dan memposisikan bayinya dengan nyaman terutama saat menyusui. Hal ini akan membuat ibu fokus pada dirinya sendiri tanpa memerdulikan bayinya. Adanya keluhan nyeri yang ibu rasakan dapat membuat ibu beralih pada pemberian ASI menggunakan dot bahkan memberikan susu formula. Hal tersebut terlihat dari rendahnya keyakinan ibu mengenai tidak akan menggunakan dot untuk menyusui (mean $=3,08)$.

Selain akibat dari adanya nyeri, penggunaan dot juga dapat disebabkan oleh adanya responden yang bekerja dalam penelitian ini $(31,2 \%)$. Ibu yang kembali bekerja biasanya memompa ASI kemudian memasukannya ke dalam botol untuk bayinya ketika sedang bekerja. Namun seringkali juga ibu yang tidak bekerja memakai dot jika akan berpergian atau sedang diluar rumah. Hal ini dikarenakan ibu merasa malu jika harus menyusui didepan umum dan ibu merasa memperlihatkan payudara hanya untuk konteks seksual saja. Padahal menurut Roesli (2010) pemberian ASI dengan menggunakan dot akan mengakibatkan refleks menelan bayi berkurang karena air susu dapat mengalir dengan mudah dari lubang dot sehingga rahang bayi kurang berperan dalam proses menelan. Pemberian ASI lewat dot juga akan meningkatkan resiko bengkaknya payudara. Kedua hal tersebut akan mengakibatkan produksi ASI berkurang.

\section{Self-Efficacy Dalam Menyusui Berdasarkan Dimensi Dukungan}

Pada dimensi dukungan, lebih dari setengah responden memiliki tingkat selfefficacy yang tinggi. Tinginya self-efficacy pada dimensi ini disebabkan oleh dukungan emosional dan fisik yang sudah ibu dapatkan dari suami $($ mean $=3,13)$ dan keluarga (mean= 3,20) sudah optimal. Menurut Murray dan McKinney (2014), dukungan yang paling berpengaruh adalah dukungan dari suami dan orang tua. Hal ini juga sesuai dengan hasil penelitian Ida dan Joko (2015) yang menyatakan bahwa terdapat hubungan bermakna antara dukungan keluarga (ibu dan ibu mertua) dengan perilaku pemberian ASI eksklusif.

Dalam kehidupan rumah tangga di Indonesia, keikutsertaan pengambilan sebuah keputusan di dalam rumah tangga seringkali tidak hanya melibatkan antara suami dan isteri saja namun juga melibatkan pendapat 
dari masing-masing keluarga besar isteri dan suami, salah satunya adalah ibu dan ibu mertua. Hal ini dikarenakan ibu dan ibu mertua seringkali menjadi panutan bagi ibu menyusui. Ibu menyusui akan mengikuti nasehat yang diberikan oleh ibu dan ibu mertua karena kedua orang tersebut dianggap lebih berpengalaman dalam mengurus bayi termasuk dalam menyusui. Dengan memaknakan pembelajaran menyusui yang ibu dapatkan dari keluarga, ibu akan memilih untuk menyusui dan dapat berhasil mencapai keberhasilan menyusui.

Namun, dukungan yang ibu dapatkan dari teman masih rendah (mean $=2,75)$ baik dukungan dalam membantu posisi ibu saat menyusui $($ mean $=2,66)$, pujian yang didapatkan ibu jika berhasil menyusui (mean= 2,73), dukungan dalam memberikan tips dalam menyusui (mean $=2,88)$ dan motivasi yang didapatkan (mean= 2,86). Padahal menurut Murray dan McKiney (2014) teman dapat dijadikan sumber diskusi mengenai menyusui karena biasanya komunikasi antar sesama teman akan lebih terbuka dan baik. Namun pada penelitian ini, dukungan yang ibu dapatkan dari teman lebih rendah oleh bila dibandingkan dengan dukungan dari sumberlainnya.

Berdasarkan jenis informasi yang yang ibu dapatkan dari petugas kesehatan, rata-rata informasi mengenai perawatan payudara masih rendah (mean= 2,86). Kurangnya informasi yang didapatkan dari petugas kesehatan dapat membuat ibu menerima informasi yang salah. Untuk itu diperlukan peran petugas kesehatan dalam meningkatkan pelayanan dan penyuluhan yang berhubungan dengan cara perawatan payudara untuk kelancaran pengeluaran ASI.

\section{SIMPULAN}

Secara keseluruhan, lebih dari setengah ibu post seksio sesarea mempunyai tingkat self-efficacy dalam menyusui yang rendah. Jika dilihat dari masing-masing dimensi, kurang dari setengah responden memiliki tingkat self-efficacy rendah pada dimensi teknik dan dimensi kepercayaan intrapersonal. Rendahnya self-efficacy dari kedua dimensi tersebut disebabkan oleh kurangnya pemahaman ibu mengenai teknik menyusui sehingga kepercayaan ibu pun berkurang. Namun pada dimensi dukungan, lebih dari setengah responden memiliki tingkat self-efficacy yang tinggi. Hal ini disebabkan oleh mayoritas ibu mendapatkan dukungan dari suami dan keluarga. Rendahnya self-efficacy ibu post seksio sesarea saat menyusui dapat berpengaruh pada rendahnya komitmen ibu untuk menyusui dan rendahnya daya tahan ibu terhadap hambatan yang dialami saat menyusui sehingga ibu beresiko berhenti menyusui terutama jika dihadapkan pada kesulitan.

\section{DAFTAR PUSTAKA}

Bandura. 1977. Self-efficacy: Toward a Unifying Theory of Behavioral Change. Psychological Review, 84(2), 191-215

Blyth R., Creedy DK., Dennis CL., Moyle W., Pratt J., De Vries SM. 2002. Effect of Maternal Confidence on Breastfeeding Duration: an Application of Breastfeeding Self-efficacy Theory. Birth. 29 (4):278-84.

Coca. 2008. Does Breastfeeding Position Influence The Onset of Nipple Trauma?. USP, 43:442-8.

Dennis, CL. \& Faux, S. 2003. The Breastfeeding Self-efficacy Scale: Psychometric Assessment of The Short Form. JOGNN.32(6):734-44.

1999. Development and Psychometric Testing of The Breastfeeding Self-effiacy Scale. Research in Nursing \& Health.22:399409.

1999. Theoretical Underpinnings of Breastfeeding Confidence: A Selfefficacy Framework. Journal of Human Lactation. 15: 195. 
Fahriani, R. 2014. Faktor yang Memengaruhi Pemberian ASI Eksklusif pada Bayi Cukup Bulan yang Dilakukan Inisiasi Menyusu Dini (IMD). Sari Pediatri. Vol. 15, No. 6.

Ida, I. \& Joko, I. 2015. Pemberian Dukungan Untuk Menyusui ASI Ekslusif Enam Bulan di Puskesmas Kemiri Muka, Depok, Jawa Barat, Tahun 2011. Jurnal Kesehatan Reproduksi. Vol. 6 No. 1.

Karlström, A., \& Hildingsson, I. 2007. Postoperative Pain After Cesarean Birth Affects Breastfeeding And Infant Care. Journal of Obstetric, Gynecologic, \& Neonatal Nursing, 36(5), 430-440.

Kemenkes RI. 2015. Profil Kesehatan Indonesia Tahun 2014. Jakarta: Kemenkes RI.

Kurniawan, B. 2013. Determinan Keberhasilan Pemberian Air Susu Ibu Eksklusif. Jurnal Kedokteran Brawijaya, Vol. 27, No. 4.

Lin, S., Lee, J., Yang, C., \& Gau, M. 2011. Factors Related to Milk Supply Perception In Women Who Underwent Cesarean Section. Journal of Nursing Research, $19 \quad$ (2), 94-100. doi:10.1097/JNR.Ob013e31821988e9.

Murray, S. S. \& McKinney, E. S. 2014. Foundations of Maternal-Newborn and Women's Health Nursing. Missouri: Elsevier.
Pollard, D. \& Guill, M. 2010. The Relationship between Baseline Selfefficacy and Breastfeeding Duration. Southernonline Journal of Nursing Research, 9 (4).

Rinata, E. 2015. Teknik Menyusui yang Benar Ditinjau Dari Usia Ibu, Paritas, Usia Gestasi dan Berat Badan Lahir Di RSUD Sidoarjo. Midwiferia, 1 (1).

Roesli, U. 2010. Mengenal ASI Ekslusif. Jakarta: Pustaka Pembangunan Swadaya Nusantara.

Spaulding, D.M. \& Gore, R. 2009. Breastfeeding self-efficacy in women of African descent. JOGNN. 38, 230-243.

Sullivan, C. J. 2014. Does The Type of Delivery and Hospital Practices Impact Breastfeeding Self-Efficacy and Outcomes at 10 Days and 8 Weeks Postpartum. Dissertation Doctor of Philosophy Nursing George Mason University.

WHO \& Unicef. 2014. Global Nutrition Targets 2025: Breastfeeding Policy Brief.

Wiklund, I., Edman, G., Ryding, E-L, \& Andolf, E. 2008. Expectation and experiences of childbirth in primiparae with caesarean section. BJOG, 324-331. doi: $10.1111 /$ j.1471-0528.2007.01564.x 